Women: A Cultural Review

\title{
Mending the Torn Fragments of a Relationship: An Interview with Sarah Strong
}

\section{Valerie Heffernan}

To cite this article: Valerie Heffernan (2018) Mending the Torn Fragments of a Relationship: An Interview with Sarah Strong, Women: A Cultural Review, 29:1, 97-111, DOI: 10.1080/09574042.2018.1425538

To link to this article: https://doi.org/10.1080/09574042.2018.1425538

\section{曲 Published online: 29 Mar 2018.}

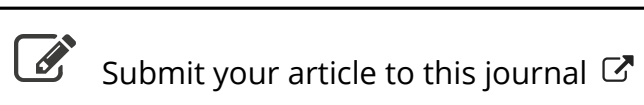

山 Article views: 31

Q View related articles $₫$

View Crossmark data 
Mending the Torn

Fragments of a

Relationship: An

Interview with

Sarah Strong

Abstract: Sarah Strong is a practising artist who lives in Islington, London. In this interview, Strong describes her charged and at times very difficult relationship with her mother, the Irish poet Eithne Strong (1923-99), as well as her unconventional upbringing in a commune on the south side of Dublin. She discusses her decision to leave Ireland for London after discovering she was pregnant, and contemplates the joys and challenges of becoming a mother at a young age, far from bome and in difficult economic circumstances. This interview also highlights how Strong's relationship with her mother, as well as with the maternal more generally, has found expression in her visual art and, more recently, in her film and poetry.

Keywords: exile, Irish poetry, maternal art, migration, motherhood, short film

Look, I'll never leave you, issue

of my bone: inside

the marrow's marrow tissue

I am true no matter what.

But I must not be your slave

and do not suck my later life.

I, of sweat and pain have

given, and breaking labour.

Let me be. There is much

I am starving for. 
No muffler I to scarf your

years. I cannot aye be shield.

Rebellion? Yes. I am but part

grown. We grow till death.

Let me space. I cry for stars

as in my callow years. (Strong Eithne 1974: 30)

Sarah Strong is a practising artist who lives in Islington, London. The daughter of the Irish poet Eithne Strong (1923-99) and English psychoanalyst and writer Rupert Strong (1911-84), Sarah grew up in a commune on the south side of Dublin. In this interview, she speaks about the artistic richness of her background, as well as the difficulties of growing up in such an unorthodox familial environment, and she discusses the impact that both have had on her life and work. She also explores how her relationships with her poet mother and her sister, the artist Rachel Strong (1950-2003), have found expression in her visual art and, more recently, her film and poetry.

After leaving Ireland at the age of 18, Strong studied architecture at the Architectural Association School of Architecture, graduating in 1976. She spent her early professional life in the development of social housing, especially housing cooperatives. As she notes in this interview, this is ironic given that her initial years living in London were characterized by poverty and homelessness. Always interested in the body and its connection to expressions of emotion, Strong retrained as an osteopath at the age of 39 , and she ran a clinical practice for over 20 years.

The death of her father prompted Strong to return to art as a means of dealing with the powerful, often contradictory thoughts and emotions that she experienced at this challenging time. In this interview, she describes how her initial forays into visual art revolved around embryonic images and the maternal body. She also explains why she chose to adopt an alter ego for these paintings, which she found difficult to relate to at times. Strong returned to college in 2004, studying fine art at Central Saint Martin's School of Art and Byam Shaw School of Art for two years. Her art exhibitions include Caoin-Lament at the London Irish Women's Centre (2011), Nere Perspectives on Women and the Irish Diaspora at Bath Spa University (2012) and Migration: Mothers and Daughters at Mind Yourself in London (2013). Particular artworks are held by the Dublin Writers Museum and City of London Academy, Islington.

In more recent years, Strong has begun to explore other media for her artistic expression. Her poetic film I Hear Fish Drowning premiered at the Merriman Summer School in County Clare, Ireland, in 2014 (Strong 2014). Her poetry has appeared in a number of journals and anthologies, 
including Washing Windows? Irish Women Write Poetry (Arlen House, 2017) and Soutbword (spring 2017).

This interview highlights the centrality of the mother-daughter relationship to Sarah Strong's artwork. It explores how issues of loss and longing, exile and homelessness have found expression in different facets of her work at various stages in her life. Strong speaks openly about her fraught relationship with her mother and how her attempts to connect with herboth personally and artistically-were repeatedly rebuffed. She also describes how making her film, I Hear Fish Drowning, enabled her to repair the torn fragments of her sense of self, to mend her frayed relationship with her home and her past, and to reconnect with her mother through a shared commitment to art and poetry.

\section{London, 17 November 2016}

Valerie Heffernan (VH) : I'd like to start by asking you about your childhood. You had a relatively unusual childhood, born in a commune in Dublin as one of nine children to two very strong parents. What was that like?

Sarah Strong (SS): I was born in January 1949, the very month in which they started the commune. As a child, I think I carried something symbolic for this group of very well-intentioned but naive people, whose aim was to set up a commune which would offer refuge and support to people who were emotionally disturbed, outside of the therapeutic setting. It was a group of psychoanalysts who had come together under the pioneering umbrella of Jonathan Hanaghan, who had brought psychoanalysis to Ireland in the 1930s and, with my father, Rupert Strong, set up the first Irish Psychoanalytic Association in 1942. They were all Protestant and English. What they were trying to do was to bring the teachings of Jesus and Freud together. About five families came together originally. They weren't wealthy and they operated a sort of Robin Hood system for patients.

The house we lived in-a big house on about six acres-belonged to a rich patient, and we paid a nominal rent. The house was surrounded by post-war corporation houses; on all sides were very poverty-stricken families, 12 or 15 living in a two-up two-down. The locals didn't like us; we were odd. The local story was that people went into the house we lived in and didn't come out again. And so it was a very rarefied and lonely way of growing up, in that we were so different and making friends was hard. But we met people who came for therapeutic help from all over the world, from different cultures and classes. And my father was a socialist and tried to help the local Irish families in whatever way he could. 
1 The term 'Breac Irish' refers to the Irish living in communities where a mixture of Irish (Gaelic) and English was spoken. The term breac, which means 'speckled' or 'mottled', was first used formally in 1925 when the Gaeltacht Commission sought to define the various regions of Ireland according to the language spoken by the local population. The BreacGaeltacht consisted of those communities where Irish was spoken by between 25 per cent and 80 per cent of the population.
Although the idea had been to live together and that the women would share the housework, in fact it fell apart very early. Eithne was extremely attractive to men. That created a lot of envy and friction. They had an ethos of open marriage and exploring sexual relationships, which made everything very complicated.

VH: What was your relationship with your mother like then? Were you aware as a child that she was a poet?

SS: I have no memories of closeness with Mummy at all. She was a very unusual woman. She came from a Breac Gaelic background, ${ }^{1}$ but they were middle class. Both of her parents had acquired an education; they were teachers. They had an extremely rigid Catholic background. In a sense, although she went from a repressive regime into an apparently bohemian one, it, too, was actually a repressive and patriarchal regime in terms of the women. The rule of authority in the commune was Jonathan Hanaghan, and everything revolved around that. Mummy was unique in that commune among the women in holding her ground, in that she asserted her right to lovers. She also asserted her right to free time for her writing. But she never asserted her right to birth control. She was not a woman who wanted lots of babies, but she had them, and I, from very early on, felt her rejection. A story she used to tell me when I was growing up was that before she became pregnant with me, she had got a place at [the Royal College of] Surgeons to become a doctor and she had to forgo that.

I was aware of her always being a poet. She always made time somehow for it. She had a place where she would work. Books would appear with her poetry in it, beautifully produced volumes, and she would have poems in them from as long as I can remember. She began publishing in 1942 after all, and so there were always little snippets of her poetry appearing in various things. Then, when I was 12, in 1961, her first collection was published: Songs of the Living. I think her publication Flesh: The Greatest Sin is one of her best books, and it really gives a sense of how she was damaged by the sexual repression of the Catholic Church. It was as though when she met Rupert, who was 12 or 13 years older than her, with this ethos of exploring a different kind of sexuality, she went over the top, you know, went the other way.

I was very aware always of what was happening to her body. I was very interested in that. Maybe that's where I became interested in the body. Whenever she was pregnant-which was often-as soon as it happened, I can remember we'd go, 'Wow, great, Mum! That's marvellous!' It was always a great source of celebration. From the age of five, I could change a nappy. I took on a role of helper to her. I would get up at five in the morning from the age of eight and peel the potatoes, make the fire, set 
the breakfast. She always said she couldn't do without me, but she really resented my trying to control everything, organize the children and boss them. And she hated that, saw it as a criticism.

It's puzzled me how in her interviews in later life, she used to ponder about why none of her daughters except for me had managed to finish their education or lead a professional life and earn money for themselves -in other words, to be economically independent, except for me. She seemed baffled by it. But the reality was that between 1968 and about 1972, her other teenage daughters, apart from me, had about six children between them. Very early on, about seven or eight, I can almost feel the moment where I realized, 'I'm clever and that's a tool'. Education is a tool. And somehow that saved me!

\section{VH: How did you make the decision to move to London?}

SS: As I said, my father used to open the house to various people, so there were always people living with us. One of the people to whom he gave a home, Yaman, is my son Luke's dad. He had been made homeless, put out on the street by his parents, and so my father took him in and he lived with us. I'd never met someone like that, a man who was very clever but also could cook, sew and knit. He was a real feminist in those days. In the beginning, he got condoms from Northern Ireland, so we used birth control, and then there was a point when we thought we wanted to make a baby. I was still in school, in my last year. And so we stopped using them. I never thought it through, you know; we were teenagers, were caught up in passion. And so I became pregnant. I didn't feel able to tell anybody, nobody at all, none of my sisters, nobody. Yaman had come to London to work. I had a friend, a doctor, who was an intern at the Richmond Hospital. Off my own bat, I gave him some urine, and he took a test, and he said, 'Yes, you're pregnant. You're going to have your baby on 10 January'. So, I thought, 'Right, fine. I'll have my baby'. Luke Campbell, my son, was born on 3 January 1968, to my great joy.

During that period when I was pregnant, I didn't really want to go to school. This is where I have one memory of being close with Eithne-one of only two really. She wanted to get away to write something, so she went off to the countryside for two weeks, and I said I didn't want to go to school, because I wanted to study on my own. So we went to the country together. We were both working-she writing and me doing my revision for my Leaving Cert[ificate]. Every evening we would read Peig Sayers. It is the only time we were really close, but she didn't know I was pregnant. I never told her.

And so I came to London and married Yaman. That was the beginning. I never knew I was leaving for good. It was heartbreaking to leave because I 
loved Ireland-the country, the people, the scenery, and my parents and siblings. I came here, and it was very, very hard. We had no money, nowhere to live. I got myself a job within a couple of weeks. I got a job as a telephonist because of my posh accent [laughs]. And I worked until eight weeks before Luke was born.

\section{VH: Did you have much contact with home after you left?}

SS: There was very little contact, very little. When I said to them I was coming to London, my father said, 'You'll get pregnant'. And he wept. I was supposed to go to Trinity [College Dublin] to do English literature. I think I was my father's favourite child. Had I stayed, I can see what the scenario was. He wanted me to go to Trinity to do English lit and then go into publishing. He had one of his colleagues lined up for me to marry. That was the scenario in the commune: you keep the girls close, marry them to the psychoanalysts, they have the babies. I got away-and I'm glad I got away!

Luke's father, my first husband, was very supportive of my education and saw me as a colleague, a collaborator. He valued my gifts and skills, and he supported them. I don't know how I would have got a grant without his help to guide me, because I was very naive and not very practical.

\section{VH: When did you first come to art?}

SS: The only other moment I remember being close to Mummy, apart from the one where we read Peig, was when I was about five or six. She pulled out a portfolio. It was a very tender, special time when she showed Rachel and me her drawings and paintings. Somehow I've always held onto that memory. The point is that she identified Rachel very early on as the artist in the family and me as the clever one. So, from about 7 to about 16 , I concentrated on all my exams. Then, in my teens, I thought I was hopeless at art, although I did it. I kept comparing myself to Rachel, who had a natural flair-she was just born with it. That comparison meant I was always diminishing my own gift in that arena.

But then I began to think about doing interior design, and, in fact, that's what I did start off with. When Luke was a baby, I saved myself from falling apart-from isolation, loneliness and homesickness-because I was always making things. You know, I'd turn the table into a sculpture or put collage over the wall. I would make toy boxes. Then, while I was waiting to get a grant-you had to be here for three years-I started preparing a portfolio. First, towards the end of my twenty-first year in 1970, I did a year of interior design at Hammersmith College of Art and Building, and then I transferred to architecture at the Architectural Association School of Architecture. So, art was always there really. But I had to earn money. Yaman and I divorced when Luke was five, so I had to earn my living. 
After my father died [in 1984], the bottom fell out of my world. I then began re-engaging with art because I was going through Jungian analysis and it was like a lifeline. I started having these extraordinary, terrifying dreams and I literally thought I was going mad. Art gave me a sort of containment. It was a lifeline for me. It was then that I really began to blossom, and ever since, it's been with me.

VH: What kinds of images did you initially gravitate towards?

SS: I started doing embryonic things; I was absolutely obsessed with the forming of the child. This (Figure 1) is huge; it's the first canvas I ever made; it's $5^{\prime} \times 8^{\prime}$. I love that my son and his wife have it in their house. My mother saw the canvas in his house and said, 'Oh, who did that?' And Luke said, 'It's one of Mum's'. And she said nothing.

This one (Figure 2) came about because I was obsessed with breaking eggs. I think that's very interesting in terms of the maternal. I actually got eggs physically and broke them by squeezing them. I just had to break them open-and this came out of that, as though I was trying to break through something. To me, now looking in hindsight, in terms of the core and the placenta and the whole business of an amniotic fluid and containers, I think that's a very interesting image.

VH: And yet you call it Mean and Evil?

SS: Yes, I did call it Mean and Evil. I think Mummy didn't want me because she had a place at [the Royal College of] Surgeons. I think when she found she was pregnant, her message through that pre-verbal place was 'You're not wanted'. I think these artworks are me. I think they're all aspects of me.

VH: At what point did you tell your mother that you were drawing and painting?

SS: I told her in the early 1990s. I didn't tell her, but I just sent her maybe three photographs and she never commented. I didn't see her very often. I just might see my parents maybe briefly once a year. I hated going back to Dublin. I hated being in the ethos of the community that still existed, although not in the same form. I found my family so dysfunctional; I hated to be in its atmosphere. My way of keeping in touch with Ireland, which I loved, was that I bought an old ruin of a cottage in West Cork and did it up. Luke and I used to go there for our summer holidays and work on it. I might go to Dublin or they might pop down, but I didn't really see much of them.

VH: You have three different names in your artwork over the years-Una, Stella and Sarah. Can you tell me about these different personas? What or whom do they embody for you? 


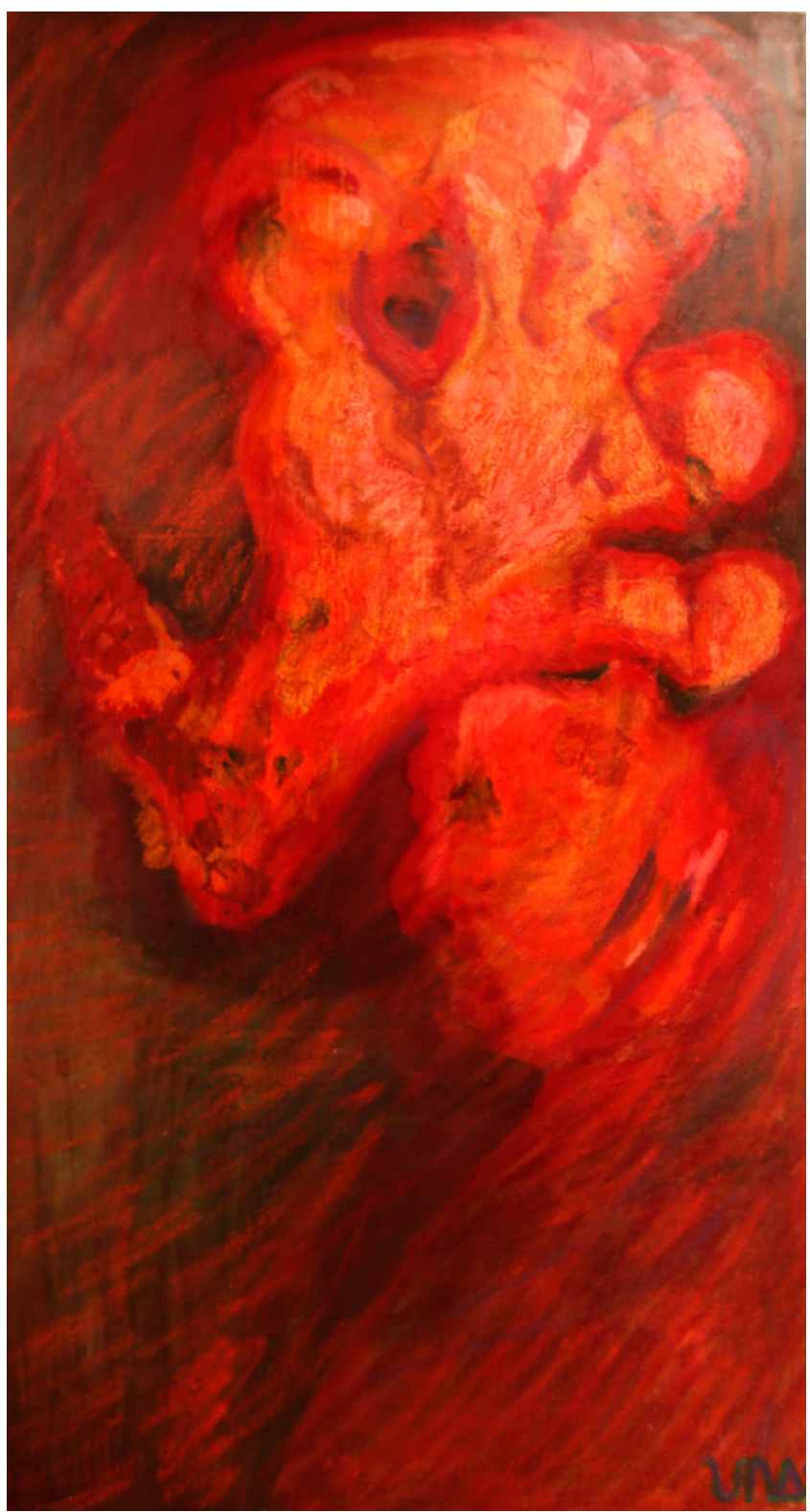

Figure 1. Embryo. Oil on canvas, $6^{\prime} \times 4^{\prime}$ (C 1995 Sarah Strong, all rights reserved).

SS: I'll start with Una. When I was sort of getting cascades of images, I chose the name Una because, first of all, it was a name my mother chose for me and it's Irish, though it doesn't have the fada on it. Looking back, it seems to me that because it means 'one' in Latin, it gave me a vehicle to contain the 


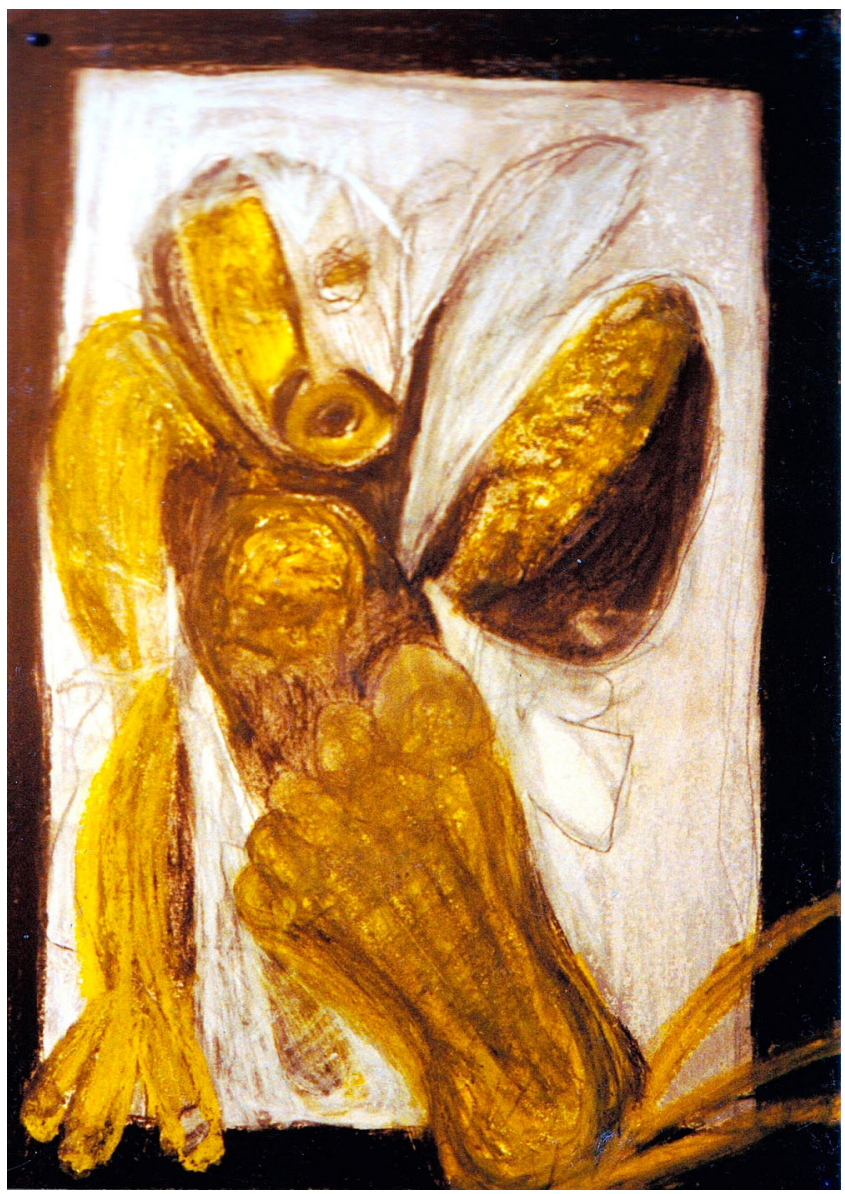

Figure 2. Mean and Evil. Pastel on paper (C) 1994 Sarah Strong, all rights reserved).

unsayable, which was pouring out, spilling relentlessly. I couldn't use my own name. Some of the material was so shocking and appalling that I couldn't actually believe what I was drawing. I still notice that I use the name occasionally, when the subject matter is disturbing or has a sinister charge. Una embodies for me the ability to hold polarity and dark material without going mad.

So Una began in the early 1990s. My mother died in 1999, and there were circumstances around her funeral which I wanted to distance myself from. And on the eve of the millennium, I found myself at midnight in a grove of laurels in Devon. And I just spontaneously stuck my head into icy water, and I called on laurels, because they're the sign of victory. And I just chose the name Stella; it's like I pulled a star out of the sky. And it 
was an act of assertion after the way my mother's death and its aftermath had fractured me. I had to find a name that would help me deal with skeletons in the cupboard. And so Stella came about. And then I later recalled that Mummy had written a poem in which one of the lines was, 'I cry for stars as in my callow years'. And then I remembered that I'd actually used that line in an essay for the Architectural Association about women's housing, because it's from her book Sarah, in Passing from 1974. I continued to use Stella in my art practice throughout the early 2000s.

Then, in 2003, my sister Helen drowned herself-the worst thing that ever happened to me-and then, five months later, Rachel died in tragic circumstances. She was a heroin addict and had a very troubled life. So Stella was really important because, then again, I became flooded with images that I could hardly contain. Stella's persona allows me a wider, more spacious viewpoint, like the eyes of a dragonfly, to understand that there are many perspectives. She's wise and seeking to integrate negative archetypes and images. She wants to move from needy child to mature adult in a compassionate way.

Sarah is the name I was given at birth, and I use it now more consistently than others. I really liked when I was growing up that it was connected with a powerful woman matriarch in the Bible, and I like the sibilance, and so ... For many, many years, until really quite recently, I found it very hard to say my name. But I've grown to feel very comfortable with the name now, because I missed having the sound around. And now, for me, it embodies my different selves as I learn to mother myself again, knowing that the process of maternal art-making is more about me than my mother, ultimately.

VH: Your film, I Hear Fish Drowning, explores issues of loss and of exile, which are seen in terms of your relationship to your mother and in terms of your relationship to Ireland. Can you tell me about the process of making that film? What inspired you to make it? And what kind of emotions did it evoke in you?

SS: It's been an extraordinary five years for me, artistically the richest of my life. And it all began when I knocked spontaneously on the door of the London Irish Women's Centre. When I was doing the exile course-'Women and Exile in Irish Literature and Culture', a 12-week project run by Dr Ellen McWilliams-which was over quite a long period, I found again, compulsively, I was up at night. I started writing a document over about three weeks; it must have been about 10,000 words. I called it Ruainne, which means 'fragments' in Irish. And it was all about lots and lots of different issues in my childhood, all in a sort of mosaic form.

Then, at the beginning of 2012-I always like to do something at the beginning of the year, a gesture of intent or hope about growth-I thought, 'I'm going to send this document off to someone'. And so I 
sent it to a film-maker whose work I admired. Within 24 hours, he came back and said, 'I really like this film. I'd like to do something with it'. We had conversations for about four or five months. And what I began to do was to pull a thread out of that, a thread around exile and belonging and around my mother, and I made it into a screenplay.

For all sorts of reasons, which I won't go into right now because it's too long a story, I decided not to go with him. I said to [my husband] John, 'For Christ's sake, why don't we make it ourselves?' And he said, 'Yeah!' (He's an artist too and an architect.) We were actually incredibly naive because, of course, although we'd both been at Saint Martin's, where everybody was making films, we'd never done it. So, that was the starting point.

And so it began! We stepped off into the darkness, actually. We had to learn step by step by step. Luke, my son, is a film-maker, and he was laughing at us. Then there was a day he came round here and he saw all the things we were doing. He saw we were serious, and he said, 'I'll give you a list of people who you could write to, see if they're interested'. He acted as our executive producer for the film.

Because Luke works in a commercial field, the people I approached were commercial; they'd no experience of an art film but because it was an art film, they were interested in doing it gratis. We could only work with them when they were available, so it took two years to make a 20 -minute film. We took on different roles. I loved working with the children, making the costumes and the directing. John and Luke did the camera work. John and I talked about the use of the colour palette-you know, how the red runs through it like a current -trying to get nuances. It's deliberately cryptic. We didn't want it to be a linear narrative; it is deliberately oblique.

\section{VH: Was it difficult or challenging for you to work with film?}

SS: For me, film is deeply visual, and so I didn't see that as an issue. What you are doing is making the story like a comic strip, and you're trying to construct images. So it's not that different. The difference is that you're having to think about viewpoints, the technicalities, the lighting. All those things were very tricky! But the actual making of a story, telling the feelings, the medium was very conducive.

It's done so much for me that I can't tell you! I mean, acting in it, the use of my body. Because all my life, since a child, I internalized so much that I've had lots of bodily difficulties. To use my body, it was lovely! I really felt that physically! My nervous system felt as though a cellular reprocessing was happening. It was therapeutic in the way that Judith Butler refers to it-performance, the performative.

In the film, I had the ability to render Eilis, who acts the woman at the Irish Women's Centre, as my good-mother archetype, and then the bad- 
mother archetype runs through it represented by the red dress. I made that red dress, and to have it ripped up, I can't tell you! Still my hairs on my body go up! The daring to do it! The daring to rip my mother's dress! One of the best things was when I was coaching-directing the children from the Young Actors Theatre Islington. The young actress obviously only had one chance to rip the dress, so we practised with bits of material, ripping, because we had to get it just right (Figure 3).

And I found something deeply poignant about it-and challenging. It was both. But it's mended something is all I can say. It's about putting something back together again. I love to restore things, to give new life to things. Whether it's healing someone because their body's broken or, you know, refurbishing a house. So, maybe it's mending the broken part of me that got so fragmented.

VH: I wonder, do you connect the idea of sewing and mending with the maternal?

SS: Yes, that's a very good point! Mummy was a marvellous seamstress! She made all her clothes. She had this cupboard with boxes of Vogue patterns, and Rachel and I would sit in that cupboard on the floor and take them out. And then we would watch her making everything. She never showed us how to sew, but we learned through watching her. And we had great fun, Rachel and I, as teenagers, making and designing clothes.

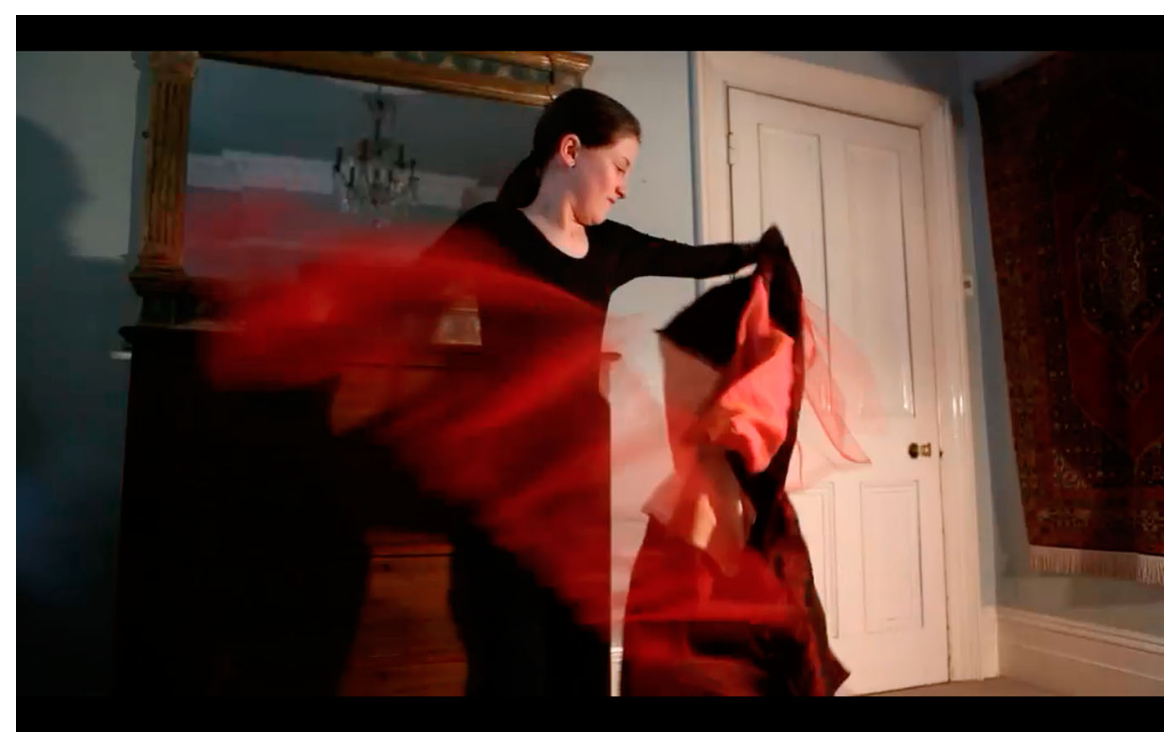

Figure 3. Film still from I Hear Fish Drozening, directed by Sarah Strong and John Hodge (C) 2014 Paulownia Pictures, all rights reserved). 
In terms of the film, the person who plays Eithne is sewing the dress at the table. When the dress is torn, we deliberately let the camera pan over it, sort of like a lover; it lingers on the torn pieces. It almost takes on the shape of the body. It becomes both a caress and a sort of murder. Because I couldn't touch Mummy in the way I wanted to as a child, there is enormous rage and, behind that, it's all about sorrow! And also, what a waste! What a waste of a relationship! It seems so sad!

Just at the end of the film, I walk through Eithne's poem. The film opens deliberately with her poetry at the beginning and at the end, and so they're like portals. And at the end, I walk her poem; I walk through it by talking it. I'm trying to recognize something about myself, and it's reparative, restorative. And Stella is allowed to do it, because she's that wise alter ego.

When I was invited to Merriman to show the film, which was the Irish premiere, it was in Ennis, where my mother went to school. She went to Coláiste Muire. It was as though I was being invited back to her territory. The hotel I stayed in was called the Old Ground; I found that very interesting! And then, when I showed it and it got such a tremendous reception, it felt like I was being allowed to be mutual, alongside her, on her ground, in Ennis. And I felt such a profound sense of peace! I remember just sitting afterwards, after everyone had gone, just sitting there and feeling such a profound sense of peace. I think what's happened is that all the troubles and fragments have actually settled and I've aligned on the axis mundi of inhabiting my own landscape-with the blessings of Amergin and the long line of Irish poets behind me!

VH: That brings me to my final question. You have recently begun to write and publish poetry, which is, of course, very significant given your mother's background. Is there a sense where you are also taking up your mother's torch?

SS: Well, both my parents were poets, so maybe in a way, and it was a natural milieu. It was sort of around us all the time and, as a child, I did write poems, but then I stopped, until now. In my childhood, I used poetry as a way of dealing with stuff. And it's interesting that Rachel kept those poems. Even when she was dying, she said, 'You know, I kept those poems because they meant something to me'.

But I think all these creative mediums overlap and interweave, you know. I don't see, I've never understood the idea of separating things. Like, you know, to me, art and architecture, poetry, film, they're all sort of facets on a diamond. And I like that image of the crystalline self and the Diamond Sutra, where we try to come back to our adamantine selves. Maybe that's what the film has done for me.

Just that I think that the whole process, particularly the film really, has allowed me to find a profound sense of Irish identity. Because by, in a way, 
re-enacting being in the middle of the Irish Sea, going backwards and forwards in the film between England and Ireland, between adulthood and childhood, I think perhaps I was recreating that initial migration. Because when I left in 1967, I never realized I was migrating. Pat Coughlin uses a very interesting reference around migration. She says it is a form of splitting, and I think that is right. I think that what's happened now is that I've brought the English and Irish together, knitted the two halves, the yin and the yang.

'An Irish Woman Writer'

for Eithne Strong, 1923-99

She scoops words into her pockets, a child on her hips.

Her pockets are wide and deepher secret place where she keeps throbbing thoughts free from household rabble.

Hurried, scribbled notes on dockets from Greers and Findlaters; she pushes them into her brassiere where they blot with milk. One baby follows another. A toddler tugs her hair, spectacles lurch, the glass crazed.

She cooks stew with one hand, wipes a runny nose, with the other.

Like a Hindu deity, her arms are everywhere.

At night, in her blue dressing-gown, she sips silence. Lights her desk, (a baby by her feet), lifts her Parker pen to foolscap sheets- (Strong, Sarah) 


\section{Acknozledgements}

The excerpt from Eithne Strong's poem 'Statement to Offspring' is included here with the kind permission of Dr Kevin Strong. 'An Irish Woman Writer' (C) 2016 Sarah Strong, all rights reserved) is included here with the permission of Sarah Strong. All the images are included here with the permission of Sarah Strong.

\section{Disclosure Statement}

No potential conflict of interest was reported by the author.

\section{Funding}

This research was funded by an Irish Research Council Starter Research Project Grant [strand RPG2013-1].

\section{ORCID}

Valerie Heffernan (1) http://orcid.org/0000-0002-9960-8213

\section{Works Cited}

Strong, Eithne (1974), 'Statement to Offspring', in Sarah, in Passing, Dublin: Dolmen, p. 30.

Strong, Sarah and John Hodge (dir.) (2014), I Hear Fish Drowning, London: Paulownia Pictures, at www.paulowniapictures.com. 